DOI: 10.20472/IAC.2019.052.019

\author{
KRZYSZTOF ECHAUST \\ Poznań University of Economics and Business, Poland
}

\title{
HOW DO MARKET MOVEMENTS AFFECT OPTIONS PRICES?
}

\begin{abstract}
:
According to the theory of financial engineering the valuation of financial instruments takes place in the risk-neutral pricing framework. In this case, the valuation of financial instruments is made without taking into account the risk and, as a consequence, the influence of market movements on options valuation is ignored. In this work, we try to check whether the valuation of call and put is independent on the condition of the capital market. We analyse investors propensity to buy call options during the bull market and put options during market downturns. In this study 678 options series listed on Warsaw Stock Exchange are considered in the period from 2007 to 2018. The results of the conducted research indicate differences in the valuation of both types of options. Put options are priced with a higher level of volatility in times of extreme risk, but the valuation of call options does not depend on situation on the financial market.
\end{abstract}

\section{Keywords:}

implied volatility, option, call, put, pricing

JEL Classification: G13, G10 